\title{
Political Science in the Legacy of Classical Islamic Literature
}

\section{Ṭāhā Jābir Al-'Alwānī}

In my own limited knowledge I know of no specialized studies in our classical legacy which could be described today as political thought, or as treatises on political systems, international relations, systems of government, the history of diplomacy, political development, methods of political analysis, political theory, political planning, or any of the other categories currently studied as a part of contemporary knowledge.

Nonetheless, many of the issues discussed on these subjects were treated in the classical legacy through the medium of fiqh (laws of Islam), which in its long history touched upon many of the subjects studied today in the social sciences. Likewise, many of the questions dealt with in the field of political science were addressed by the early scholars of Islam within the framework of their writings on classical Fiqh of al Ahkam al Sultaniyah (the Precepts of Power). Perhaps the book written by Shaykh Ibn Taymiyah, al Siyāsah al Shar'iyah, was one of the most distinctive efforts in this direction as well as the book by al Khatib al Iskafi, Luț al Tadbïr, which also dealt with certain issues which remain relevant today. Similar to such works are Suluk al Malik Fi Tadbir al Mamalik, Badäi al-Silk, and others.

These works show that the meaning of politics to the Muslim mind, and as envisioned by Islam, involves making arrangements for mankind in accordance with the values prescribed by Allah (SWT) for the realization of His purposes in creation, and in fulfillment of the trust of vicegerency, the duties of civilization, and the responsibility of the Ummah to act as a witness unto all mankind in its capacity as the "Middlemost Nation."

"Making arrangements" includes reading the past and learning its lessons as well as interpreting, understanding, and analyzing the present in the light of those lessons. Other elements included in "making arrangements" are planning for the future and benefiting from all scientific knowledge that clarifies

Dr. Al- 'Alwānī is President of The International Institute of Islamic Thought, Herndon, VA. An Arabic version of this article was presented by him as the opening address at the Seminar on Political Science, sponsored by The Association of Muslim Social Scientists in cooperation with The International Institute of Islamic Thought, held Dec. 15-17, 1989 at the International Institute of Islamic Thought, Herndon, VA. 
the particularities of the present. In such an endeavor, a certain kind of penetrating, striving intellect is necessary. This particular kind of genius and ability is what the classicial jurists (fuqahä) called fiqh al nafs, inherent religious/legal acumen, an attribute of someone for whom understanding and analytical capacity have become second nature.

\section{Challenges Faced by the Muslim Scholar}

There are significant challenges confronting the Muslim scholar of political science. Two fundamental issues often prevent the development of a comprehensive and objective view of matters.

First, the Muslim scholar of political science has an inherent difficulty in dissociating the political aspect from other scholarly aspects. These may include the sources of Islam, such as the Quran and Sunnah, the sourcemethodology employed to interpret these texts, or the comprehensiveness of figh legislation. It is difficult, perhaps impossible, to place well-defined divisions among these aspects in the same way that there are divisions among the various contemporary social sciences.

This point was made all the more obvious by the recent experiences of certain Islamic universities, where departments of Siyãsah Shar'iyah (the science of Shari'ah-based principles and conduct of government) have been newly established. They have had a very difficult time in presenting material on political science in the Islamic tradition in a methodical manner befitting the educational and academic purposes for which they were established. Indeed, the models of application from Islamic history, the variety of experience in terms of how closely, or otherwise, these models approximated the stated Islamic ideal, the different positions adopted by the traditional scholars visa-vis such models, all of these factors give credence to the statement that Islamic culture and learning are bereft of a science of Islamic political thought.

Second, this intellectual void forced the imposition by default of Western political perspective and experience as authoritative sources in the field of Islamic political science. Yet the Western political perspective is based on values which, when applied by the Muslim scholar, actually impede understanding of the Islamic political system. In addition, those values are unsuitable agents for change or development in an Islamic context. Among the most prominent values espoused by Western thought, and those which act to obstruct an understanding of the proper Islamic perspective, are the following:

Islam is no more than a religion like any other; and since it is a religion, it should not differ in any significant way from 
the Christianity of the Middle Ages in Europe, in the sense that the church was duty-bound to stand in the way of progress. From this perspective, whatever development was accomplished by humanity could never have come about were it not for the split between church and state; after a long and bitter struggle, Western man emerged triumphant over the church and all that it represented. Thus, it is inconceivable that a Westerner could imagine a link between knowledge and religion, to say nothing of accepting the notion of basing the humanities and social sciences on religion or giving them a religious perspective.

Islam is a religion, and religion relies solely on revelation, to the point where reason and empirical knowledge are relegated to marginal roles. With such a view, it is considered absurd to suppose that a social science could be based on religion, particularly a discipline like political science, which gives weight to human experience and empirical knowledge.

The sources of religion, based as they are on revelation, are thus subject to interpretation primarily by means of the language in which the religion was revealed. So the determination of its truths is thus said to depend entirely on that language.

The sources of religion are historical in the sense that they are linked with the events of a particular period of time. Under this view, the historicity of those sources stands between any serious academic work produced within the framework of that religion and, furthermore, negates any attempt at generalization.

These misconceptions demand that contemporary Muslim political scientists, today more than ever, mobilize all the resources available so as to be able to unflaggingly pursue, on the one hand, the introduction of a revolution of thought in the Ummah of Islam and, on the other, the establishment of sound academic foundations for an Islamic science of Shari'ah-based principles and conduct of government. In this way, Muslims may regain their identity, and be encouraged to work for the regeneration of the Ummah as an influential international power capable of wresting the reins of leadership from the forces of evil and from self-assumed superiority on earth. 


\section{Steps Along the Way}

Perhaps the proper beginning for a Muslim political scientist who is aware of the truths expressed above would be the comparative study of some of the topics listed below:

1. Tawhid, the absolute Oneness of Allah (SWT) as divine entity and lord $(R a b b)$.

2. Absolute sovereignty of Allah (SWT), and exclusiveness of revelation (Wahy) as the source of legislation.

3. Revelation and the universe as sources of knowledge.

4. Reason, the senses, and experiment as means of attaining knowledge.

5. Unity in the Ummah of Islam, and the uniqueness of the Ummah in its character and meaning.

6. The concept of Khiläfah (man's vicegerency) and the dignity of man and that which distinguishes him from the rest of creation.

7. Affliction and its repulsion.

8. Permanence of the source of values.

9. Oneness of ultimate truth and reality.

10. Taskhï (utilization rather than exploitation).

When we consider these principles, it is difficult to perceive any real resemblance between them and those upon which other civilizations are based.

As a second step for the Muslim scholar of political science, it would seem appropriate to work on presenting a complete conception or design, based on the principles indicated above, of how a Muslim may practice politics in the contemporary world, how politics are linked to Shari'ah obligations, how present-day political practices and institutions may be considered Islamic or at least capable of substantiating Islamic objectives in areas like individual political expression, Shürā, and enjoining the good and prohibiting what is evil. Another question that must be answered is how to implement truly Islamic alternatives in current political configurations.

Without a doubt, the history of Islam produced a variety of examples of polity which approximated, in some cases, the ideas of justice and good government and, in others, the worst forms of oppression, injustice, and tyranny. Certain fiqh scholars were lenient in their acceptance of the latter circumstances, while others adopted positions of suitably steadfast opposition, so that they struggled against the tyranny of their rulers and maintained the integrity of Islamic values and the lucidity of Islam's purpose. This, nonetheless, has not left us with an integral understanding of the questions considered 
to be of contemporary importance. Among these are the following:

What is the true nature of shürā? How is the principle to be expressed, and how may it be participated in? What sort of institutions need to be established in order to realize shürā? How is the Ummah to be prepared to make use of shürā? How are the circumstances of the Ummah's history to be analyzed in order that lessons may be drawn from it? What is to be the effect of fiqh on Islamic political thought, practice, and institutions? How is the Ummah to be involved practically in the political process? What are the means of bringing the Ummah to a state of political competence? What kind of institutions are needed for such an undertaking? What are the guarantees which the contemporary scholar of political science may glean from the teachings of Islam, that could be presented at a legislative and institutional level, regarding preventing a ruler from abusing his office and toying with the rights of the Ummah? What are the guarantees and fundamental concepts to be presented to the non-Muslim minorities living in Islamic states? How may they participate in politics and government where the majority is clearly Muslim?

Certainly there have been, in the course of the last century, several serious attempts to establish Islamic states within the part of the world commonly perceived as the Muslim homeland. Yet, many of these have failed, among other reasons, because of the inability of Islamic political thought to meet the fundamental conceptual needs of the contemporary Islamic state and the ineptitude of today's Muslim thinkers in presenting a contemporary Islamic fiqh of government and politics that would be suitable as a base for the establishment of a sound and distinct Islamic policy.

Still, the Muslims as a people, through the medium of various Islamic movements, have exhibited their ability to spur the Ummah on to the achievement of its goals and to engender within it the spirit of jihad so that it is capable of making the greatest of sacrifices. There are many examples of this, but perhaps the most obvious are of the jihad in Afghanistan and the Intifäda in Palestine. But in spite of this ability, the Muslim mind remains incapable of capitalizing on these advances and putting them to good use. Indeed, the revolutions in the Islamic world are the best example of this phenomenon. Political scientists and scholars of fiqh, despite the differences in their disciplines, are clearly in the best position to suggest solutions to these problems.

The fiqh of politics and government which is needed by the Ummah at present must turn to the goals and purposes of Islam, to its general principles, 
and to its precepts. In this way, a complete system of political thought may be developed to interact with contemporary realities for the realization of Islam's greater purposes. In this endeavor, it is imperative that theories be derived from the basis of accepted Shari'ah source-evidence, while drawing from the experience of historical and contemporary humanity.

The necessary source-evidence for the contemporary Muslim scholar in this endeavor will, of course, begin with the Qur'an and Sunnah, ijma (consensus of the scholarly community), and qiyàs (analogical reasoning). Beyond these four sources, there are other less known, but certainly valuable sources of Islamic law. These include Maslahah Mursalah (the greater good), Istishāb (assessment of circumstances), Bara'ah (legal license), 'Ädah (custom), A'araf (legal convention), Istiqra (induction), Istdilal (deduction), Istihsan (legal preference), Sad al Dhara'i (obstruction of pretexts), and Akhdh bil Akhaff (acceptance of the least imposing).

Indeed, a study of other than the first four mediums of source-evidence will satisfy the Muslim scholar that there is a great scope and suitable benefit for the exercise of the intellect in establishing the fiqh of government and politics. 